\title{
Mycophenolate Mofetil - Necessity of Monitoring of the Drug Level in Blood Patients after Kidney Transplantation
}

\author{
Dziewanowski K ${ }^{1 *}$, Drozd $\mathbf{R}^{2}$, Krzystolik $\mathbf{A}^{3}$ and Ostrowski $\mathbf{M}^{4}$ \\ ${ }^{1}$ Centre of Nephrology and Kidney Transplantation Regional Hospital, Poland \\ 2Department of General Surgery and Transplantation, Pomeranian Medical \\ University, Poland
}

*Corresponding author: Krzysztof Dziewanowski, Nephrology and Kidney

\section{Research Article}

Volume 1 Issue 1

Received Date: October 09, 2017

Published Date: October 30, 2017

DOI: $10.23880 /$ ijtps- 16000104

Transplant Center, ul. Arkońska 4; 71-455 Szczecin, Poland, Tel: 918139613, E-mail: krzysztof.dziewanowski@gmail.com

\section{Abstract}

The authors, based on data from the literature and our own clinical experience, analyze the need for continuous monitoring of the levels of immunosuppressive drugs used in patients with renal transplant. They are convinced that the accurate and frequent determination of blood levels of calcineurin inhibitors, mTOR inhibitors, and in selected cases of mycophenolate mofetil, is now a necessity.

Monitoring levels of MMF AUC method is particularly useful in optimizing the dose of the drug, and thus can contribute to a reduction in side effects and may minimize risk of rejection.

Keywords: Kidney transplantation; Immunosuppression; Area under the curve

Abbreviations: MMF: Mycophenolate Mofetil; MPS: Mycophenolate Sodium; HPLC: High Performance Liquid Chromatography; EMIT: Enzyme Multiplied Immunoassay Technique; FPIA: Fluorescence Polarization Immunoassay; MEIA: Microparticle Enzyme Immunoassay; G6PHD: Glucose-6-Phosphate Dehydrogenase; NAD: Nicotinamide Adenine Dinucletide; AUC: Area under the Curve.

\section{Introduction}

Wide introduction of calcineurin inhibitors in transplantation since the 1980s resulted in a significant improvement in survival of both transplants and patients. However, when we use these and other immunosuppressive drugs we constantly have to achieve balance between the need to protect the patient against rejection and the potential toxicity of these medications.
In extreme cases we can even speak of the so-called "immunosuppressive disease" which results from multiple adverse effects of these drugs affecting multiple organs and causing disorders such as arterial hypertension, diabetes, bone marrow toxicity, predispositions to cancer and infections, as well as acute or chronic nephrotoxicity. Therefore, modern transplantology commonly recommends monitoring of blood levels of the most commonly used immunosuppressive drugs.

This applies to both calcineurin inhibitors (cyclosporine, tacrolimus, Advagraf) as well as mTOR inhibitors (Sirolimus, Everolimus). During the use of monoclonal (OKT3) and polyclonal antibodies (ATG, Thymoglobulin), it is necessary to check leukocytosis, and more preferably, the level of CD3 lymphocytes (decrease 


\section{International Journal of Transplantation \& Plastic Surgery}

in the number of these cells during treatment should not exceed more than 50-100/ $\mathrm{mm}^{3}$ of blood) [1-8].

Among clinicians there is a discussion whether levels of mycophenolate mofetil (MMF) or even mycophenolate sodium (MPS) should be routinely monitored. Therefore, we would like to present our initial experience with this issue.

Large individual variability in metabolism of calcineurin inhibitors forced the need to monitor their blood levels in patients undergoing organ transplantation. Most of the centers assess the so-called $\mathrm{C}_{0}$ level - that is the concentration of the drug at 12 hours after of administration. Determination of the so-called $\mathrm{C}_{2}$ (that is the drug concentration at 2 hours after administration) is less accepted due to the lower reliability of the data received. Assessment of area under the curve of drug levels is not as widespread because of problems with its practical use, and because of the costs. Concentration of CyA can be assessed both in serum and whole blood. The used methods are: HPLC - high flow chromatography (high performance liquid chromatography), EMIT (enzyme multiplied immunoassay technique) or FPIA (fluorescence polarization immunoassay). MEIA (Microparticle Enzyme Immunoassay) is the most commonly used method to assess the concentration of tacrolimus, and it is based on the determination of monoclonal antibodies in automated analyzers. Recommended concentration levels of drug in the blood of these patients are dependent on the time period after the transplantation as well as the applied research methodology. For example, in the initial phase after transplantation, $\mathrm{C}_{0}$ of CyA should be $250-450 \mathrm{ng} / \mathrm{ml}$, and after a few months, about $150 \mathrm{ng} / \mathrm{ml}$ (FPIA method). The similar applies to concentration of $\mathrm{C}_{2}$ - initial values should be $1.5-2 \mathrm{mg} / \mathrm{ml}$, and later 0.8 to $1.0 \mathrm{ug} / \mathrm{ml}$. Recommended levels of tacrolimus $\left(\mathrm{C}_{0}\right)$ for the initial dose of $0.15 \mathrm{mg} / \mathrm{kg} \mathrm{/} \mathrm{day} \mathrm{in} \mathrm{the} \mathrm{early} \mathrm{period} \mathrm{after}$ transplantation should be in the range of $10-20 \mathrm{ng} / \mathrm{ml}$, and after a few months between 5-7 $\mathrm{ng} / \mathrm{ml}$.

Determination of the AUC involves adding up the drug blood levels in a number of samples taken within a few hours after ingestion. It is emphasized that there are significant differences between absolute values of measurements of the original drug concentration compared to its generic formulations [9-11].

Recommended blood level of mTOR inhibitors is within range of 5-25 ng/dL using HPLC method. It is emphasized in the literature that combination of these drugs with calcineurin inhibitors should be used with extreme caution because both these groups of medications are metabolized by the same cytochrome in liver (P-450 III A cytochrome) $[12,13]$.

\section{Methods}

In our center, since April 2016, we have conducted plasma level MPA analysis performing enzyme immunoassay EMIT method using a homogeneous enzyme immunoassay technique.

These tests were conducted on an analyzer produced by Siemens based on the principle of competition for binding sites of MPA- antibodies

MPA present in the sample competes with the MPA labeled with an enzyme, glucose-6-phosphate dehydrogenase (G6PHD). Active, unbound form of the enzyme converts nicotinamide adenine dinucletide (NAD) into an antibody (a substrate for NADH), which results in a change of absorption which can be measured spectrophotometrically. Since the enzyme activity decreases after binding with the antibody, it allows to measure concentration of MPA in the sample. Using this research method we have performed 23 AUC tests (with three samples of blood for each of them) in 21 patients until now.

\section{Results}

The graph depicting measured values is presented below (Figure 1).

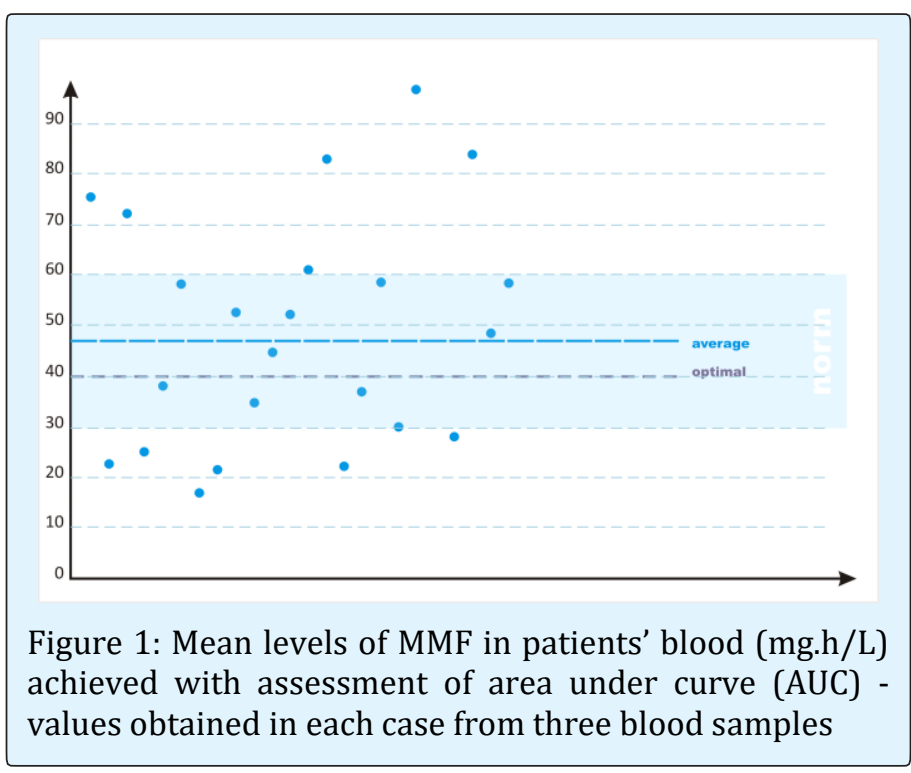




\section{International Journal of Transplantation \& Plastic Surgery}

The average assessed value of AUC was $46.96 \pm 21.98$ (recommended AUC is 30-60 mg.h / L, the optimal is 40 mg.h / L). In several cases the AUC values differed far from the recommended range, which resulted in correction of drug dose. In one case of highly increased AUC (75 mg.h / L), the patient developed symptoms of CMV infection and we believe that a significant reduction in the dose of MMF facilitated prompt control of this infection.

\section{Discussion}

Assessment of blood levels of mycophenolate mofetil (particularly the most commonly used formulation mycophenolate mofetil) is still controversial. A number of transplant centers routinely use the manufacturer's recommended dose of $2 \mathrm{~g} /$ day $(2 \times 1,0 \mathrm{~g})$ in adult patients, at most modifying it according to the weight of the patient or dividing daily dose into 3-4 doses in case gastrointestinal adverse effects occur. However, an increasing number of clinical studies and literature reports criticize such mode of treatment. They believe that a number of adverse effects of this drug can result from an uncontrolled increase of its level in blood despite administration of a recommended dose. Also, greater frequency and severity of graft rejection may in some cases be the result of a low level of drug in the blood despite the typical dosage $[14,15]$. There are at least two methods of monitoring blood levels of this drug. The first involves determining the concentration of mycophenolic acid in the blood MPA $\mathrm{C}_{0}$ immediately before the next dose. This is a simple way, requiring only a single blood draw. The recommended level of MPA $\mathrm{C}_{0}$ when it is administered in combination with CyA is $1,3 \mathrm{mg} / \mathrm{L}$ and, when MMF is co-administered with tacrolimus, it is 1.9 $\mathrm{mg} / \mathrm{L}$. However, a disadvantage of this method is a low correlation of obtained $\mathrm{C}_{0}$ values with area under the curve (AUC). Therefore, it is currently preferred to use a three-point assessment system, that is determination of drug concentration in the blood at $20 \mathrm{~min}, 1$ hour and 3 hours after administration. It is assumed that the recommended aggregate values of mycophenolate mofetil levels assessed by this method should be in the range of 30 - 60 mg.h / L, taking into account that different values are necessary in patients co-treated with CyA or tacrolimus [14].

Currently there are big difficulties in developing a practical method for monitoring the level of mycophenolate sodium (MPS) which becomes more increasingly used in transplantation centers because of intolerance of mycophenolate mofetil caused by gastrointestinal adverse effects in some patients. These difficulties arise from the fact that the administration of mycophenolate mofetil is followed by an almost immediate release of this drug in the gastrointestinal tract, while in the case of mycophenolate sodium (MPS) this process is delayed which may partly be due to different individual rate of gastric emptying [16]. It is further complicated by widespread use of proton pump inhibitors which can cause premature dissolution of the tablets and faster release of the active drug. It is attempted to solve this problem by monitoring blood levels of the drug at 3 and 4 hours after ingestion. Currently, clinical trials are performed in order to develop optimal assay method [17-20].

\section{Conclusions}

The above review of the literature, clinical trials and our initial experience suggest clearly that monitoring the levels of immunosuppressive drugs, especially after kidney transplantation, is a necessity. It seems that this also applies in selected cases to monitoring blood levels of mycophenolate mofetil, which is reflected by an increasing use of these assays in transplantation centers.

\section{References}

1. Sabatini S, Ferguson RM, Helderman JH, Hull AR, Kirkpatrick BS, et al. (1999) Drug substitution in transplantation: a National Kidney Foundation white paper. Am J Kidney Dis 33(2): 389-397.

2. Bodziak K., Hrick D (2003) Minimizing the side effects of immunosuppression in kidney transplant recipients. Current Opinion in Organ Transplantation 8(2): 160-166.

3. KDIGO Transplant Work Group (2009) KDIGO Clinical Practice Guideline for Care of Kidney Transplant Recipients. Am J Transplant 9(3): S1-155.

4. Durlik M, Rowiński W (2010) Zalecenia dotyczące leczenia immunosupresyjnego po przeszczepieniu narządów unaczynionych. Fundacja Zjednoczeni dla Transplantacji. Warszawa. Grudzień.

5. Gill JS, Tonelli M, Mix CH, Johnson N, Pereira BJ (2004) The effect of maintenance immunosuppression medication on the change in kidney allograft function. Kidney Int 65(2): 692-699.

6. Kanmaz T, Knechtle SJ (2003) Novel agents or strategies for immunosuppression after renal 


\section{International Journal of Transplantation \& Plastic Surgery}

transplantation. Current Opinion in Organ Transplantation 8(2): 172-178.

7. Perico N, Ruggenenti P, Gotti E, Gaspari F, Cattaneo D, et al. (2004) In renal transplantation blood cyclosporine levels soon after surgery act as major determinant of rejection: insight from M.Y.S.S. trial. Kidney Int 65(3): 1084-1090.

8. Meier-Kriesche HU, Li S, Gruessner RW, Fung JJ, Bustami RT, Barr ML, et al. (2006) Immunosuppression: Evolution in practice and trends, 1994-2004. Am J Transplant 6(5 pt 2): 11111131.

9. Doyle I, Zikri A, Bennett WM, Shaw LM, Figurski MJ (2010) Area under the curve (AUC ) bioequivalence (BE) of mycophenolate mofetil (MMF): Cell Cept vs generic. Abstract presented at the American Society of Nephrology. Renal Week 2010. Denver 1621.11.2010.

10. Kunicki PK, Pawiński T (2012) Równoważność biologiczna preparatów generycznych leków immunosupresyjnych - różnice farmakokinetyczne i konsekwencje dla terapii monitorowej stężenia leku. Nefrol Dial Pol 16(4): 181-186.

11. Yang CW, Ahn HJ, Kim WY, Li C, Kim HW, et al. (2002) Cyclosporine withdrawal and mycophenolate mofetil treatment effects on the progression of chronic cyclosporine nephrotoxicity. Kidney Int 62(1): 20-30.

12. Figurski MJ, Nawrocki A, Pescovitz M, Rene B, Leslie S (2008) Development of a predictive limited sampling strategy for estimation of mycophenolic acid area under the concentration time curve in patients receiving concomitant sirolimus or cyclosporine. Ther Drug Monit 30(4): 445-455.

13. Mendez R, Gonwa T, Yang HC, Weinstein S, Jensik S, et al. (2005) A prospective, randomized trial of tacrolimus in combination with sirolimus or mycophenolate mofetil in kidney transplantation: Results at 1 year. Transplantation 80(3): 303-309.
14. Pawiński T (2010) Terapeutyczne monitorowanie stężenia kwasu mykofenolowegow terapii immunosupresyjnej - zalecenia I wątpliwości. Reaktywacja 3: 13-15.

15. de Jonge $H$, Naesens M, Kuypers DR (2009) New Insights into the Pharmacokinetic and Pharmacodynamics of the Calcineurin Inhibitors and Mycophenolic acid: possible consequences for therapeutic drug monitoring in solid organ transplantation. Ther Drug Monit 31(4): 416-435.

16. Kees MG, Steinke T, Moritz S, Rupprecht K, Paulus EM, et al. (2012) Omeprazole Impairs the Absorption of Mycofenolate Mofetil but not of Mycofenolate Sodium in Healthy Volunteers J Clin Pharmacol. 52(8): 12651272.

17. Sommerer C, Müller-Krebs S, Schaier M, Glander P, Budde $K$, et al. (2010) Pharmacokinetic and pharmacodynamics analysis of enteric-coated mycophenolate sodum: limited sampling strategies and clinical outcome in renal transplant patients. $\mathrm{Br} \mathrm{J}$ Clin Pharmacol 69(4): 346-357.

18. Arens W, Breuer S, Choudhury S, Taccard G, Lee J, et al. (2005) Enteric-Coated Mycophenolate sodum delivers bioequivalent MPA exposure compared with mycophenolate mofetil. Clin Transplant 19(2): 199206.

19. Cooper M, Salvadori M, Budde K, Oppenheimer F, Sollinger H (2012) Enteric-coated mycophenolate sodium immunosuppression in renal transplant patients: efficacy and dosing. Transplantation Rev 26(4): 233-240.

20. Salvadori M, Bertoni E, Budde K, Holzer H, Civati G, et al. (2010) Superior efficacy of enteric-coated mycophenolate vs mycophenolate mofetil in de novo transplant recipients: pooled analysis. Transplant Proc 42(4): 1325-1328. 